
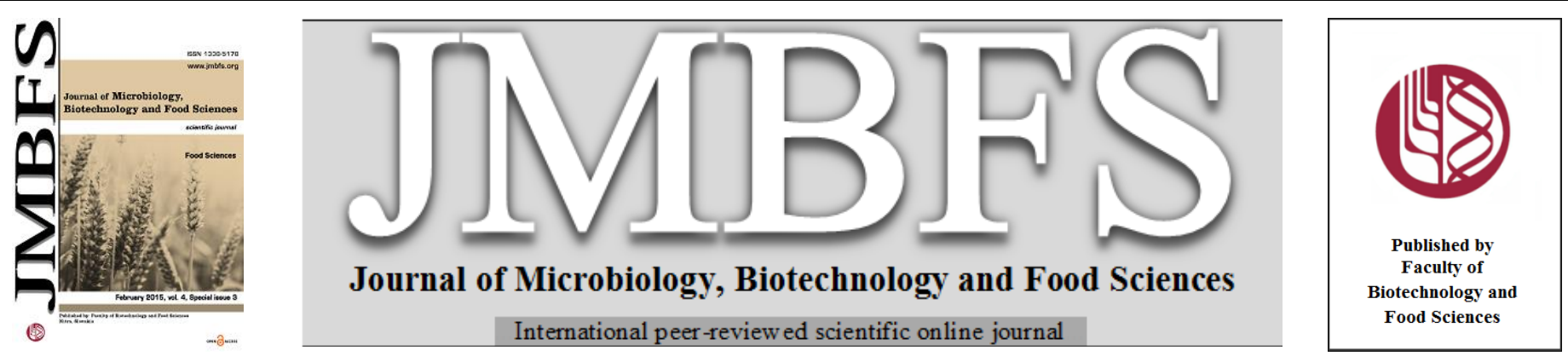

\title{
FARINOGRAPHIC EVALUATION OF WHEAT DOUGH ENRICHED WITH INULIN, NAKED BARLEY, MALT AND POTEX ADDITION
}

\section{Marián Tokár*, Tatiana Bojňanská, Helena Frančáková, Eva Ivanišová, Štefan Dráb, Karolina Mocko, Hana Balková}

Address(es): Ing. Marián Tokár, PhD.

${ }^{1}$ Slovak University of Agriculture, Faculty of Biotechnology and Food Sciences, Department of Plant Products Storage and Processing, Trieda A. Hlinku 2, 94976 Nitra, Slovak Republic, +421 376415815.

*Corresponding author: marian.tokar44@gmail.com

doi: 10.15414/jmbfs.2015.4.special3.157-160

\section{ART ICLE INFO}

Received 30.11.2014

Revised 6. 12. 2014

Accepted 8. 12. 2014

Published 2. 2. 2015

Regular article OPEN $\bigodot_{\text {ACCESS }}$

\begin{abstract}
One of the most important biological substances consumed in insufficient quantity is fibre that is often deficient in the diet. In general, dietary fibre is edible part of plants, or similar carbohydrates, that are resistant to digestion and absorption in the small intestine. Nowadays, there are many sources of fibre available for bakery industry, whether through addition of non-traditional bread cereals or through isolated form as additives. Except to supposed increase the nutritional value of bakery products with added fiber and raw materials containing fiber is necessary to think about their technological quality and rheological properties of dough. The aim of this experimental work was to investigate the effect of the addition of selected polysaccharides (inulin,Potex - potato fiber) and non-bakery crops (naked barley, malt) containing significant polysaccharides used in the mixture with wheat flour typ e T-650 in different ratios on the basis of farinographic evaluations. Based on the results of rheological measurements we found out that quality of dough was deteriorating proportionally to the amount of used additives. On the other hand, positively could be considered the increase of water absorption with addition of Potex and naked barley.
\end{abstract}

Keywords: Farinograph, wheat dough, inulin, naked barley, malt, potex

\section{INTRODUCTION}

Bread and pastries are basic foods consumption of which in Slovakia, despite the downturn in recent years still reaches high numbers, around $67 \mathrm{~kg}$ perperson per year. However, considering the technology of milling of cereals, where the milling process changes the appearance and nutrition value of cereal grains by separating the bran and germ from the endposperm and reducing the particle size (Barbosa and Yan, 2003), it is appropriate to consider the enrichment of bread with nutritionally important ingredients that would increase its nutritional benefits for consumers and technological properties (Paturi et al., 2012). One of the groups of biologically important substances consumed in insufficient quantities is fibre, which is often deficient in the diet. Generally speaking, dietary fibre is the edible parts of plants, or similar carbohydrates, that are resistant to digestion and absorption in the small intestine (Lattimer and Haub, 2010). There are many beneficial effects of increased dietary fibre consumption on human health and body function. Many studies have confirmed the beneficial effect of fibre on human health, especially on the physiology of digestion (Fardet, 2010; Yikyung et al., 2011; Gong and Yang, 2012). In addition to the favourable preventive effect on development and progression of gastrointestinal diseases, such as colon and rectum cancer, chronic inflammation of the colon, gallbladder diseases, fibre is important in the prevention of so-called lifestyle diseases - type 2 diabetes mellitus, obesity, cardio-vascular diseases, etc. (Champ et al., 2003; Marcil et al., 2003; Mohamed, 2014). Except to supposed increase the nutritional value of bakery products with added fiber (Potex, Inulin) and raw materials containing fiber (naked barley) is necessary to think of their technological quality and rheological properties of dough. Measuring the rheological properties of dough intended for bread production is relatively complicated, connected with exploitation of specific equipment. Rheology studies relations between tension which the material is exposed to, final dimension of material deformation and time. It is very important to understand the rheological behaviour of bread dough as well as mechanical properties of the dough and control finished products (Př́íhoda et al., 2003, Mirsaeedghazi et al., 2008). Rheological techniques are commonly categorized according to the type of strain imposed: e.g. compression, extension, shear, torsion etc. The main techniques used for measuring cereal properties have traditionally been divided into descriptive empirical techniques and fundamental measurements (Bloksma and Bushuk, 1988). The most widely used instrument for testing therheological properties of dough is Brabender farinograph which is used to record changes in the dough consistency during the kneading. Farinograph has few disadvantages, such as a relatively large amount of test sample required for one test ( $300 \mathrm{~g}$ flour) and expressing the results in units specific to each device. Several alternative methods required smaller amounts of test sample to be developed (Ki effer $\boldsymbol{e t}$ al. 1998). These alternative methods are commonly used despite their insufficiencies, especially lower correlation between the results and the endproduct quality. (Hsam et al., 2001; Dunnewind et al., 2003; Tronsmo et al., 2003; Wang et al., 2004; Kieffer et al., 2007).

\section{MATERIAL AND METHODS}

In the work was used wheat flour type $\mathrm{T}-650$ as basic material obtained from the operating grinding mill (Vitaflóra Kolárovo, Slovak Republic). To this flour were added selected polysaccharides and cereals containing polysaccharides potentially suitable for enrichment bakery products in the quantities:

- $5 \%, 10 \%, 15 \%, 20 \%$ a $25 \%$ of the commercial manufactured inulin (DERACEL CF 20) from chicory (DERA FOOD

TECHNOLOGY, Belgium)

- $\quad 10 \%, 20 \%, 30 \%, 40 \%$ a $50 \%$ of the milling naked barley (Hordeum vulgare subsp. nudum L.), variety PRBL-4

(The Central Controlling and Testing Institute in Agriculture Spišská Belá, Slovak Republic)

$5 \%, 10 \%, 15 \%, 20 \%$ a $25 \%$ of the milling malt, variety LEVAN (HORDEUM Sládkovičovo, Slovak Republic)

$3 \%, 5 \%, 7 \%$ a $10 \%$ of potato fibre POTEX, (LYCKEBY CULINAR, Horaždovice, Czech Republic).

Composite flours were analyzed in order to determine the rheological properties by Farinograph-E, Brabender OhG, Duisburg, Germany (ICC St andard 115/1, 1992, AACC Method 54-21, 1995). The mixing curve is characterized by an ascending part that indicates the changes during the dough development process, while the subsequent decline in the resistance is taken as a sign of a steady breakdown of the dough structure upon mixing beyond the point of optimum development. Optimum development from the standpoint of bread quality may occur slightly past "mixing peak". The effect of the inulin, naked barley, malt and potex addition on consistency, water absorption, dough development time, st ability and degree of softening were established (FU = farinograph units - unit commonly used for evaluation of rheological consistency in bakery practice. It 
was defined by Brabender company. The physical equation is $100 \mathrm{FU}=1 \pm 0,03$ $\mathrm{Nm})$.

\section{RESULTS AND DISCUSSION}

Currently, rheological parameters of dough provide the best characteristics of flour quality (Muchová, 2007). Rheological properties are crucial in lot of steps of dough processing (mixing, rolling, shaping), but also during the fermentation, baking of products (Launay and Michon, 2006) and provide valuable information about the quality of wheat flour, dough characteristics and textural properties of the finished products (Chang and Fe rrari, 2000). The most widely used equipment for testing the rheological properties of dough is Brabender Farinograph. It is used for recording the changes in dough consistency during the kneading, when the three-dimensional gluten network is formed, due to the hydration of flour ingredients as proteins, st arch, non-starch polysaccharides and others.

\section{Addition of inulin}

Inulin is one of the well-known functional ingredients, which can be added to foodstuffs (Kováčiková et al., 2003; Solnicová, 2006; Meyer, 2007). Application of inulin in food industry is various. It is most frequently used in production of bread, pastry, confectionery, meat products, dairy products, fruit juices, non-alcohol drinks and artificial coffee substitutes. In these products, inulin reduces their energy value and allows an increased intake of soluble fiber for consumers. The average addition of inulin to foodst uffs is within the range of 5 to $10 \%$ (Konečný, 1997; Franck, 2002).

The measured values of farinographic characteristics are shown in Tab 1. In the values of water absorption was observed its growth with increased addition of inulin from $58.6 \%$ (control) to $61.8 \%$ ( $25 \%$ of inulin addition to flour), what represents an increase of 5.2\%. By Hager et al. (2011), the inulin molecules form connecting zone between water and other components of the flour mixture, which encloses a large amount of water. On the other hand, the arguments of other authors point to the fact that the replacement of starch by soluble forms of oligosaccharides and inulin leads to the reduction of water absorption and dough consistency (Rouille et al., 2005; Karolini-Skaradzinska et al., 2007; Peressin and Sensidoni, 2009). Based on the findings of our results, we agree with the view of Hage ret al. (2011). We observed an increase of water absorption with inulin addition of $20 \%$, while the differences between samples were not statistically confirmed depending on the added amount. Other measured farinographic values as dough development time and stability, degree of softening and farinograph quality number had an informative value only in the control. Farinograms with inulin addition were nonstandard, specific and their values were distorted.

Table 1 Farinographic values with different addition of inulin

\begin{tabular}{|c|c|c|c|c|c|c|}
\hline & $\begin{array}{c}\text { Consistency max. } \\
\text { [FU] }\end{array}$ & $\begin{array}{c}\text { Water } \\
\text { absorption } \\
500 \text { FU [\%] }\end{array}$ & $\begin{array}{l}\text { Development } \\
\text { time [min] }\end{array}$ & $\begin{array}{l}\text { Stability } \\
{[\text { min] }}\end{array}$ & $\begin{array}{l}\text { De gree of softening } \\
\text { (IC C) }[\text { FU] }\end{array}$ & FQN \\
\hline $\begin{array}{c}\text { flour T650 } \\
\text { (control) }\end{array}$ & 502 & 58,6 & 2,3 & 9,2 & 48 & 59 \\
\hline $\begin{array}{c}95 \% \text { T650 } \\
+5 \% \text { inulin }\end{array}$ & 402 & 56,1 & 2,2 & 18,8 & 22 & 200 \\
\hline $\begin{array}{c}90 \% \text { T650 } \\
+10 \% \text { inulin }\end{array}$ & 442 & 57,1 & 20 & 7,2 & 0 & 200 \\
\hline $\begin{array}{c}85 \% \text { T650 } \\
+15 \% \text { inulin }\end{array}$ & 499 & 58,5 & 16,5 & 8 & 0 & 200 \\
\hline $\begin{array}{c}80 \% \text { T650 } \\
+20 \% \text { inulin }\end{array}$ & 572 & 60,3 & 11 & 4,2 & 0 & 150 \\
\hline $\begin{array}{c}75 \% \text { T650 } \\
+25 \% \text { inulin }\end{array}$ & 633 & 61,8 & 10,5 & 4,4 & 0 & 130 \\
\hline
\end{tabular}

FQN - farinograph quality number

\section{Addition of naked barley}

Naked barley is underused crop suitable for the production of functional foods. It contains significant amount of beta-glucans, which are well known for their beneficial impact on the body, such as the reduction of cholesterol and glucose levels in blood and regulation of body weight (Cavallero et al.,2002; Vitaglione et al., 2009; Kinner et al., 2011). The measured values of farinographic characteristics are shown in Tab 2. There is an evident increase of water absorption with increasing addition of barley in composite flours from $63.8 \%$ (control)

to $68.0 \%$ (50\% addition of naked barley), which represents an increase of water absorption around $4.2 \%$. This effect may be considered as desirable from economic aspect, because water does not represent such a financial item as flour.

At values of dough development time, an increase in all of the barley addition in comparison with the control was observed. The highest value of dough development time was with $50 \%$ addition of naked barley. Due to the higher content of non-starch polysaccharides in barley and its larger elements (milling naked barley), there was a change in the structure of dough and then the slowdown of hydration and subsequent formation of compact homogeneous mass. As Skendi et al. (2010) mention, non-starch polysaccharides and B- glucans, which are components of fiber present in barley, were added to wheat flour and significantly prolonged the development time and st ability of dough in comparison with wheat flour alone, which corresponds with the results of our measurements.

The values of dough stability ranged from 7.1 minute (30\% addition of naked barley) to 14.7 minute (50\% addition of naked barley), whereas the sequence depending on the amount of addition was not observed.

Degree of softening is expressed as the difference between the maximum consistency and the consistency after 12 minutes (ICC). In this parameter, the values ranged from $60 \mathrm{FU}$ (control) to $97 \mathrm{FU}$ ( $20 \%$ addition of barley to flour), what can be classified as samples of medium quality. Because of insufficient measurement range, the $10 \%$ and $50 \%$ addition of naked barley were not commented. Farinographic numbers of quality had an informative value only in the control, due to thenon-standard curves in composite flours with addition of barley.

Table 2 Farinographic values with different addition of naked barley

\begin{tabular}{|c|c|c|c|c|c|c|}
\hline & $\begin{array}{c}\text { Consistency max. } \\
{[\mathrm{FU}]}\end{array}$ & $\begin{array}{c}\text { Water } \\
\text { absorption } \\
500 \text { FU [\%] }\end{array}$ & $\begin{array}{l}\text { Development } \\
\text { time [min] }\end{array}$ & $\begin{array}{l}\text { Stability } \\
{[\text { min] }}\end{array}$ & $\begin{array}{l}\text { Degree of softening } \\
\text { (IC C) }[\mathrm{FU}]\end{array}$ & FQN \\
\hline $\begin{array}{c}\text { flour T650 } \\
\text { (control) }\end{array}$ & 533 & 63,8 & 2,2 & 7,5 & 60 & 45 \\
\hline $\begin{array}{c}80 \% \mathrm{~T} 650+20 \% \\
\text { NB }\end{array}$ & 606 & 65,7 & 6,4 & 9,7 & 97 & 111 \\
\hline $\begin{array}{c}70 \% \mathrm{~T} 650+30 \% \\
\mathrm{NB}\end{array}$ & 569 & 67,2 & 6,8 & 7,1 & 90 & 110 \\
\hline $\begin{array}{c}50 \% \mathrm{~T} 650+50 \% \\
\mathrm{NB}\end{array}$ & 539 & 68 & 13 & 14,7 & 0 & 196 \\
\hline
\end{tabular}




\section{Addition of malt}

Expect of the beer production, it is possible to use the malt as a component for functional foods production (Zhao et al., 2006).

The measured values of farinographic characteristics are shown in Tab 3. With increasing proportion of malt, there was observed the decrease of water absorption from $61.5 \%$ (control) to $57.6 \%$ (25\% addition of malt) which represents decrease of $3.9 \%$. This phenomenon can be considered as a negative, which reflects to the lower yield of pastry from the same amount of flour. At values of dough development time, there was a decrease in all of the barley additions in comparison with the control (2.3 minute). The lowest dough development time was observed at $25 \%$ addition of malt (1.2 minutes). As Muchová (2001) mentioned, development time of dough below 2 minutes is characteristic for weak flour. From the above results can be deduced that the addition of malt negatively influenced the dough development time. The reason could be the absence of gluten proteins and influence of amylolytic and proteolytic enzymes high activity on the main components (starch and protein) involved in the creation of optimal dough structure.
The values of the dough stability were in the range from 1.3 minute $(25 \%$ addition of malt) to 7.7 minute (control), while the sequence from the amount of malt addition to the flour was observed and the difference between values was as much as $83 \%$. It can be stated that due to the enzymes presented in the malt, components are fractured (starch, proteins, polysaccharides) into smaller and simpler compounds that cannot create a flexible elastic dough resistant to deformation. For this reason, a trend of rapid consistency decrease after achieving maximum in the flour mixture with the addition of malt was observed. The degree of dough softening is connected with the destruction and shortening of gluten fibres and expresses dough resistance to further mechanical stress. The measured values ranged from $64 \mathrm{FU}$ (control) to $220 \mathrm{FU}$ ( $25 \%$ addition of malt), whereas with $5 \%$ addition of malt ( $145 \mathrm{FU})$, the difference to the control was almost $56 \%$. The values of the degree softening should be as low as possible, then it is a dough with minimal consistency decrease. This dough is provided only by strong flour.

In comparison with control, farinograph quality number was significantly lower in the composite flours with the malt addition.

Table 3 Farinographic values with different addition of malt

\begin{tabular}{|c|c|c|c|c|c|c|}
\hline & $\begin{array}{c}\text { Consistency max. } \\
{[\text { FU] }]}\end{array}$ & $\begin{array}{c}\text { Water } \\
\text { absorption } \\
500 \text { FU [\%] }\end{array}$ & $\begin{array}{l}\text { Development } \\
\text { time [min] }\end{array}$ & $\begin{array}{c}\text { Stability } \\
{[\text { min }]}\end{array}$ & $\begin{array}{l}\text { Degree of softening } \\
\text { (IC C) }[\mathrm{FU}]\end{array}$ & FQN \\
\hline $\begin{array}{c}\text { flour T650 } \\
\text { (control) }\end{array}$ & 521 & 61,5 & 2,3 & 7,7 & 64 & 76 \\
\hline $\begin{array}{c}95 \% \mathrm{~T} 650+5 \% \\
\text { malt }\end{array}$ & 498 & 60 & 2 & 3,6 & 145 & 36 \\
\hline $\begin{array}{c}90 \% \mathrm{~T} 650+10 \% \\
\text { malt }\end{array}$ & 508 & 59,2 & 1,5 & 2,4 & 186 & 26 \\
\hline $\begin{array}{c}85 \% \mathrm{T650}+15 \% \\
\text { malt }\end{array}$ & 524 & 58,6 & 1,5 & 1,8 & 209 & 23 \\
\hline $\begin{array}{c}80 \% \mathrm{~T} 650+20 \% \\
\text { malt }\end{array}$ & 522 & 58,1 & 1,4 & 1,4 & 213 & 19 \\
\hline $\begin{array}{c}75 \% \mathrm{~T} 650+25 \% \\
\text { malt }\end{array}$ & 523 & 57,6 & 1,2 & 1,3 & 220 & 18 \\
\hline
\end{tabular}

\section{Addition of potex}

The measured values of farinographic characteristics are shown in Tab 4. In the values of water absorption was observed it is growth with increased addition of potex from $64.3 \%$ (control) to $75.5 \%$ ( $7 \%$ of potex addition to flour), what represents an increase of $11.2 \%$. We can conclude that the addition of potex significantly increased water absorption of composite flours. It was caused by the presence of diet ary fiber components. As mentioned Camire et al. (1997), the high water absorption of potato fibre is caused by the presence of higher concentration of cellulose, hemicellulose and lignin. Height of potex addition had the greatest impact on the water absorption of flour in comparison with others addition. The potato fibers can be potentially attractive product for their unique absorption properties in food technology (Soral-Śmietana et al., 2003). At values of dough development time was observed an increased in all additions of potex to the wheat flour compared to control (2.2 minutes). The largest value of dough development time was assessment with the addition of $7 \%$. It can be expected that due to the higher content of fiber components consisting of nonstarch polysaccharides, arabinoxylan, hemicellulose, cellulose and lignin, a change in structure was occurred and thus to slow down of the hydration and to create of a compact homogeneous mass. Our findings are also confirmed by the results of the work of Kaack et al. (2006), in which the effect of pentosan on the rheological properties of dough was examined. Pentosans which are also the components of fiber increased development time and viscosity of dough. Stability of dough is defined in minutes as the time interval from the moment when the upper edge of the curve intersects the value $500 \mathrm{FU}$ and when it leaves again. The values of stability were in the range of 9.1 minutes (control) to 18.5 minutes ( $3 \%$ of the potex addition), the sequence from the amount of addition to wheat flour was not observed. Based on these results it can be concluded that the addition of potex above 3\%, significantly prolonged stability of dough. Explanation is in a slower hydration of the fiber components in the flour mixture. The values of the degree of softening were the highest in the control (58) and gradually decreased with increasing addition, while it is desirable to point out the fact that at $5 \%$ and $7 \%$ addition of potex the values were zero. It was caused by achieving of maximum dough consistency at the end of the farinograph registration and that could not be measured because of insufficient time of farinograph registration. At the values of farinograph quality number only the control and $1 \%$ addition of potex had information value, whereas the course of curves with higher additions of potex were untypical.

Table 4 Farinographic values with different addition of Potex



Legend: FQN - farinograph quality number

\section{CONCLUSION}

Based on the results obtained by observing the rheological properties of tested doughs, it can be stated that use of additives in the majority worsened the physical properties of doughs, what prediction worsening of the technological quality of final products. On the other hand positively could be considered an increase of water absorption with addition of Potex and naked barley. We can recommend the application of all these addition types in the wheat bread production, but is necessary to take into account the amount of their share of the wheat flour.

Acknowledgments: This study was supported by the project „AgroBioT ech", 26220220180 . 


\section{REFERENCES}

BARBOSA-CANOVAS, G. V., YAN, H. 2003. Powder characteristics of preprocessed cereal flour. Characterization of Cereals and Flour. Properties, Analysis and Applications. Marcel Dekker, Inc., New York, Basel, 523 p. ISBN 0-8247-0734-6

BLOKSMA, A. H., BUSHUK, W. 1988. Rheology and chemistry of dough. In Pomeranz, Y. (Ed.) Wheat chemistry and technology. St. Paul: American Association of Cereal Chemists, p. 131-217.

CAMIRE, M. E., VIOLETTE, D., DOUGHERTY,M. P., MCLAUGHLIN, M. A 1997. Potato peel dietary fiber composition: effects of peeling and extrusion cooking processes. Journal of Agriculture and Food Chemistry. ISSN 0021 8561, 1997, 45(4), 1404-1408. http://dx.doi.org/10.1021/jf9604293

CAVALLERO, A., EMPILLI, S., BRIGHENTI, F., ST ANCA, A. M. 2002. High (1 - 3,1 - 4)-beta-glucan barley fractions in bread making and their effectson human glycemic response. Journal of Cereal Science. ISSN 0733-5210, 2002, 36(1), 59-66. http://dx.doi.org/10.1006/jcrs.2002.0454

CHAMP, M., LANGKILDE, A. M., BROUNS, F., KELITZ, B., COLLETT, Y. I. B. 2003. Advances in diet ary fibre characterisation. 1. Definition of dietary fibre, physiological relevance, health benefits and analytical aspects. Nutrition Research Reviews, 16(1), 71-82. http://dx.doi.org/10.1079/nrr200254

CHANG, Y. K., FERRARI, M. C. 2000. A new apparatus for the evaluation of rheological properties of wheat gluten. Acta Alimentaria. 29, 169 - 180, ISSN 1588-2535 http://dx.doi.org/10.1556/aalim.29.2000.2.7

DUNNEWIND, B., SLIWINSKI, E. L., GROLLE, K., VLIET, T. V. 2003. The Kieffer dough and gluten extensibility rig-an experimental evaluation. Journal of Texture Studies, 34(5-6), 537-560. http://dx.doi.org/10.1111/j.17454603.2003.tb01080.x

FARDET, A. 2010. New hypotheses for the health-protective mechanisms of whole-grain cereals: what is beyond fibre? Nutrition Research Reviews, 23(1), 65-134. http://dx.doi.org/10.1017/s0954422410000041

FRANCK, A. 2002. Technological functionality of inulin and oligofruct ose. British Journal of Nutrition. ISSN 0007-1 145, 2002, 87(6), 287 291. http://dx.doi.org/10.1079/bjnbjn/2002550

GONG, J., YANG, C. 2012. Advances in the methods for studying gut microbiota and their relevance to the research of dietary fiber functions. Food Research International, 48(2),

916-929. http://dx.doi.org/10.1016/j.foodres.2011.12.027

HAGER, A. S., RYAN, L. A. M., SCHWAB, C., GANZLE, M. G., O'DOHERTY, J. V., ARENDT, E.K. 2011. Influence of the soluble fibres inulin and oat B-glucan on quality ofdough and bread. European Food Research and Technology. ISSN 1438-2377, 2011, 232(3), 405-413. http://dx.doi.org/10.1007/s00217-010-1409-1

HSAM, S. L. K., KIEFFER, R., ZELLER, F. J. 2001. Significance of Aegilops tauschii glutenin genes on breadmaking properties of wheat. Cereal Chem istry, 78(5), 521-525. http://dx.doi.org/10.1094/cchem.2001.78.5.521 KAACK, K., PEDERSEN, L., LAERKE, H. N., MEYER, A.2006. New potato fibre for improvement of texture and colourof wheat bread. European Food Research Technology. ISSN 1438-2385, 2006, 224(2), 199-207. http://dx.doi.org/10.1007/s00217-006-0301-5

KAROLINI-SKARADZINSKA, Z., BIHUNIAK, P., PIOTROWSKA, E., WDOWIK, L. 2007. Properties of dough and qualit ative characteristics of wheat bread with addition of inulin. Polish Journal of Food and Nutrition Sciences. ISSN 1230-0322, 2007, 57(4), 267-270.

KIEFFER, R., SCHURER, F., KÖHLER, P., WIESER, H. 2007. Effect of hydrostatic pressure and temperature on the chemical and functional properties of wheat gluten: studies on gluten, gliadin and glutenin. Journal of Cereal Science, 45(3), 285-292. http://dx.doi.org/10.1016/j.jcs.2006.09.008

KIEFFER, R., WIESER, H., HENDERSON, M. H., GRAVELAND, A. 1998 Correlations of the breadmaking performance of wheat flour with rheological measurements on a micro-scale. Journal of Cereal Science, 27(1), 53-60 http://dx.doi.org/10.1006/jcrs.1997.0136

KINNER, M., KINNER , S., NIT SCHKOA, J., SOMMEREGGERA, A., PETRASCHA, G., LINSBERGER-MARTIN, H., GRAUSGRUBER, E. BERGHOFER, S., SIEBENHANDL-EHN. 2011. Naked barleyd optimized recipe for pure barley bread with sufficient beta-glucan according to the EFSA health claims. Journal of Cereal Science. ISSN 0733-5210, 53(2), 225-230 http://dx.doi.org/10.1016/j.jcs.2011.01.001

KONEČNÝ, I. 1997. Pěstování čekanky. Metodika pro zemědělskou praxi. Praha: Ústav zemědělských a potravinářských informací, 1997. 22 s. ISBN 8086153-01-0.

KOVÁČIKOVÁ, E., VOJT AŠŠÁKOVÁ, A., MOSNÁČKOVÁ, J. et al. 2003 Vláknina v potravinách. Bratislava : VÚP, 2003. 30 s. ISBN 80-89088-27-9. LATTIMER, J. M., HAUB, M. D. 2010. Effect of dietary fiber and its components on metabolic health. Nutrients, 2(12), 1266-1289. http://dx.doi.org/10.3390/nu2121266

LAUNAY, B. L., MICHON, C. 2006. Rheology of Wheat Flour Doughs: Measurement. Encyclopedia of A gricultural, Food, and Biological Engineering, 2006, http://dx.doi.org/10.1081/E-EAFE-120041501
MARCIL, V., DELVIN, E., GAROFALO, C., LEVY, E. 2003. Butyrate impairs lipid transport by inhibiting microsomal triglyceride transfer protein in caco-2 cells. Journal of Nutrition, 133(7), 2180-2183.

MEYER, D. 2007. Inulins for product development of low GI products to support weightmanagement. Dietary Fibre Components and Functions. Wageningen: Wageningen Academic Publishers, 2007. 257-270. ISBN 978-90-8686-019-7. MIRSAEEDGHAZI, H., EMAM - DJOMEH, Z., MOUSAVI, S.M.A. 2008 Rheometric Measurement of Dough Rheological Characteristics and Factors Affecting It. International Journal of A griculture \& Biology, 10, 112-119. ISSN Online: 1814-9596

MOHAMED, S. 2014. Functional food against metabolic syndrome (obesity, diabetes, hypertension and dislipidemia) and cardiovascular diseases. Trends in Food Science and Technology, 35, 114-128. http://dx.doi.org/10.1016/j.tifs.2013.11.001

MUCHOVÁ, Z. 2001. Faktory ovplyvňujúce technologickú kvalitu pšenice a jej potravinárske využitie. 1. vyd. Nitra: SPU, 2001. 112 s. ISBN 8071379239. MUCHOVÁ, Z. 2007. Technológia spracovania cereálií. 2. vyd. Nitra : SPU, 2007. 192 s. ISBN 978-80-8069-980-2.

PAT URI, G., NYANHANDA, T., BUTTS, C. A., HERATH, T, D., MONRO, J. A., ANSELL, J. 2012. Effects of Potato Fiber and Potato-Resistant Starch on Biomarkers of Colonic Health in Rats Fed Diets Containing Red Meat. Journal of Food Science, 77(10), H216-H223. http://dx.doi.org/10.1111/j.1750$3841.2012 .02911 \mathrm{x}$

PERESSINI, D., SENSIDONI, A. 2009. Effect of soluble dietary fibre addition on rheologicaland breadmaking properties of wheat doughs. Journal of Cereal Science. ISSN 0733-5210, 2009, 49(2), 190-201. http://dx.doi.org/10.1016/j.jcs.2008.09.007

PRIIHODA, J., HUMPOLÍKOVÁ, P., NOVOTNÁ, D. Základy pekárenské technologie. Praha: Pekař a cukráŕ s.r.o., 2003. 363 s. ISBN 80-902922-1-6. ROUILLE, J., VALLEA, G. D., LEFEBVRE, J., SLIWINSKI, E., VLIET, T 2005. Shear and exstressal properties of bread doughs affected by their minor components. Journal of Cereal Science. ISSN 0733-5210, 2005, 42(1), 45-57. http://dx.doi.org/10.1016/j.jcs.2004.12.008

SKENDI, A., BILIADERIS, C. G., PAPAGEORGIOU, M., IZYDORCZYK, M S. 2010. Effects of two barley b-glucan isolates on wheat flour dough and bread properties. Food Chemistry. ISSN 0308-8146, 2010, 119(3), 1159-1167. http://dx.doi.org/10.1016/j.foodchem.2009.08.030

SOLNICOVÁ, S. 2006. Transformácia funkčných zložiek cereálií v potravinách nového typu: Autoreferát dizertačnej práce. Nitra : SPU, 2006. $19 \mathrm{~s}$.

SORAL-ŚMIET ANA, M., WALKOWSKI, A., WRONKOWSKA, M., LEWANDOWICZ, G. 2003. Potato fibre preparation - chemical characteristics, microstructure and functional properties in baking products. Polish Journal of Food and Nutrition Sciences. ISSN 1230-0322, 2003, 53(2), 119-124. VIT AGLIONE, P., LUMAGA, R.B., ST ANZIONE, A., SCALFI, L., FOLIAGNO, V. 2009.ß-glucan-enriched bread reduces energy intake and modifies plasma ghrelin and peptide YY concentrations in the short term. $\begin{array}{llll}\text { Appetite. } & \text { ISSN } & 01956663, & 2009,\end{array}$ 344. http://dx.doi.org/10.1016/j.appet.2009.07.013

TRONSMO, K. M., MAGNUS, E. M., BAARDSETH, P., SCHOFIELD, J. D., AAMODT, A., FÆRGEST AD, E. M. 2003. Comparison of small and large deformation rheological properties of wheat dough and gluten. Cereal Chemistry, 80(5), 587-595. http://dx.doi.org/10.1094/cchem.2003.80.5.587

WANG, M., VAN VLIET, T., HAMER, R. J. 2004. How gluten properties are affected by pentosans. Journal of Cereal Science, 39(3), 395 402. http://dx.doi.org/10.1016/j.jcs.2004.02.002

YIKYUNG, P., SUBAR, A. F., HOLLENBECK, A., SCHATZKIN, A. 2011 Diet ary fiber intake and mortality in the NIH-AARP diet and health study FREE Archives of International Medicine, 171(12), 1061-1068.

http://dx.doi.org/10.1001/archinternmed.2011.18

ZHAO, H. F., DONG, J. J., LU, J., CHEN, J., LI, Y., SHAN, L. J. et al. 2006. Effects of extraction solvent mixtures on antioxidant activity evaluation and their extraction capacity and selectivity for free phenolic compounds in barley (Hordeum vulgare L.). Journal of A griculture and Food Chem istry. ISSN 0021 8561, 2006, 54(19), 7277-7286. http://dx.doi.org/10.1021/jf061087w 